\title{
Prevalence of Mouse Mammary Tumor Virus (MMTV)-like sequences in human breast cancer tissues and adjacent normal breast tissues in Saudi Arabia
}

\author{
Reem Al Dossary ${ }^{1 *}$ (D), Khaled R. Alkharsah² and Haitham Kussaibi ${ }^{3}$
}

\begin{abstract}
Background: Breast cancer is considered the most common cancer in women worldwide and is the leading cause of cancer mortality. Sequences similar to Mouse Mammary Tumor Virus (MMTV) were detected in human breast cancer in several studies from different geographical areas. However, the role played by this virus in breast cancer tumorigenesis is not completely understood. These MMTV-like sequences were found to be associated with breast cancer of more malignant types. The aim of this study is to determine the prevalence of MMTV-like envelope gene (env) positivity in breast cancer and non-cancerous breast tissue from Saudi Arabia.
\end{abstract}

Methods: Detection of MMTV-like env proviral sequences was done using newly designed primers for conventional polymerase chain reaction (PCR). One hundred nighty four samples were collected from 103 females with breast cancer in addition to 51 control breast tissue obtained from individuals without cancer. We additionally investigated the association of proviral positivity with age of the patients, grade of breast cancer and presence of lymph node metastasis. The results were confirmed by sequencing.

Results: The prevalence of MMTV-like env proviral positivity was 8.7\% (9/103). MMTV env proviral sequences were detected in 5.9\% (6/101) of breast cancer tissues and 9.7\% (9/93) of non-cancerous adjacent tissues obtained from the same patients. None of the 51 control sample showed positive result for the MMTV env gene. No significant association was found between detection of the virus and the age of the patient, grade of the cancer or presence of metastasis.

Conclusion: We document the presence of low frequency of MMTV env provirus sequence among breast cancer patients from Saudi Arabia. Further studies are needed to explore the role of the MMTV in breast cancer.

Keywords: Mouse mammary tumor virus, Human breast cancer, Prevalence

\section{Background}

Breast cancer is considered the leading cause of cancer morbidity and mortality worldwide accounting for $23 \%$ of cancer in females and $14 \%$ of cancer mortality [1] with $40-80 \%$ five year survival rate [2].

The association between human breast cancer and viruses can be dated back to the 1971, at the University of Columbia, New York, when they first demonstrated the

\footnotetext{
* Correspondence: raaldossary@iau.edu.sa

${ }^{1}$ Department of Microbiology, Collage of Medicine, Imam Abdulrahman Bin Faisal University (IAU), 1982, Dammam 31441, Kingdom of Saudi Arabia

Full list of author information is available at the end of the article
}

presence of viral particles in human milk, by electron microscopy, which was found to be similar to Mouse Mammary tumor virus (MMTV) the causative agent of mammary tumor in mice [3]. In 1972, Axel et al. was able to detect viral particles in $79 \%(30 / 38)$ of breast cancer samples and these viral particles were found to have RNA related to Mouse Mammary Tumor Virus (MMTV) by hybridization and also carry an RNAdependent DNA polymerase (reverse transcriptase) [4]. The virus was not detected in 10 control samples.

Being a retrovirus, detection of MMTV-like proviral sequences in the pathological human samples was markedly confounded with Human Endogenous Retroviruses (HERV) 
which constitutes around $8 \%$ of the human genome. With the improvement of molecular techniques, namely sequencing, detection of MMTV-like sequences was achieved using highly specific primer pairs that detect envelope gene (env) sequences of MMTV with low homology to HERV [5]. MMTV-like env sequences were detected in 38-40\% (121/ 314 ) of human breast cancer samples, $6.9 \%$ (2/29) of fibroadenomas and 1.8\% (2/107) normal breast tissues but not in other tumor tissues and normal tissues obtained from the same patients [5]. MMTV-like 250 bp env sequences was also detected in $30.1 \%$ breast cancer samples but not from normal breast samples obtained from the same patient indicating exogenous origin of the virus [6]. MMTV-like env sequences was detected in breast cancer and lymphoma specimen from the same patient [7]. Interestingly, MMTV like DNA sequences with 98-99.6\% homology to MMTV env sequences were detected in a cluster of father, mother and a daughter with breast cancer in Canada indicating possible common source of transmission [8]. In addition, MMTV was detected in the nucleus of human breast cancer specimen using in situ PCR $[9,10]$.

Furthermore, expression of MMTV sequences was detected in $66 \%$ of DNA positive samples [11, 12] and MMTV protein was also detected in human breast cancer cell line T47D [13] and human breast tissues [14] indicating that active expression of the virus and its proteins might be involved in the pathogenesis of human breast cancer since the majority of DNA positive sample shows evidence of viral expression and protein synthesis.

Human mammary carcinoma cell line T47D was found to produce retroviral particle of $\mathrm{B}$ type morphology (eccentric dense core) which hybridize with MMTV DNA under stringent conditions and show immune reactivity with anti-MMTV antibodies [15]. To overcome the difficulty of acquiring a conclusion from an established cell line with possible contamination, primary culture of human breast cancer was developed and showed production of viral particles of B type morphology [16].

Complete structure of MMTV- like provirus, also known as Human Mammary Tumor Virus (HMTV), was described as $9.9 \mathrm{~kb}$ that show $95 \%$ and 57\% homology with MMTV and HERV-K10 respectively. Homology to HERVK10 was mainly in $3.5 \mathrm{~kb}$ region of gag and pol genes [16].

Interestingly, MMTV-like env sequence positivity was associated with more malignant types of breast cancers namely gestational and inflammatory breast cancer $[17,18]$.

Taking in consideration that MMTV-like sequence was mainly detected in breast cancers of advanced stage with the fact that breast cancer in Saudi women, particularly those of the Eastern Province, has an earlier age of onset and worse prognosis [19], we sought to determine the prevalence of MMTV positivity among Saudi breast cancer patients and correlate it with the observed pattern of the disease.

\section{Methods}

\section{Study design and samples}

A retrospective study was done to determine the prevalence of MMTV-like env proviral sequences in breast cancer tissues in the eastern province of Saudi Arabia. A total of 103 females with breast cancers were included and a total of 194 formalin fixed paraffin embedded (FFPE) samples were tested (Fig. 1). Sixty seven females were Saudi and 36 were non Saudi females living in Saudi Arabia. The samples were collected at king Fahd Hospital of the University in Al Khobar, Saudi Arabia, in the period between 2009 and 2014. Out of 194 samples, 101 samples where breast cancer tissues and 93 samples were non-cancerous normal breast tissues obtained from non-cancerous surrounding tissues of the same patients (safety margins) (Fig. 1). Additionally, 51 FFPE breast tissues from non-breast cancer patients were collected from the hospital repository. These tissue biopsies were collected either for reduction mammoplasty (5 cases) or from patient complaining of a breast mass to rule out malignancy. Twenty six of these biopsies turned to be fibroadenomas, seventeen biopsies were fibrocystic changes, two biopsies were diagnosed as duct ectasia, and one biopsy was granulomatous mastitis.

Ethical approval for this study was obtained from the Standard Committee for Research Ethics on Living Creatures (SCRELC) at Imam Abdulrahman Bin Faisal University (IRB approval number IRB-2013-01-006).

\section{Tissue preparation for extraction:}

Two $10 \mu \mathrm{m}$ sections were cut from each FFPE tissue block. A scalpel was used to trim the excess paraffin around the tissue. The tissue section was then immediately deparaffinized using deparaffinization solution (Qiagen, Hilden, Germany) according to the manufacturer's instructions. To

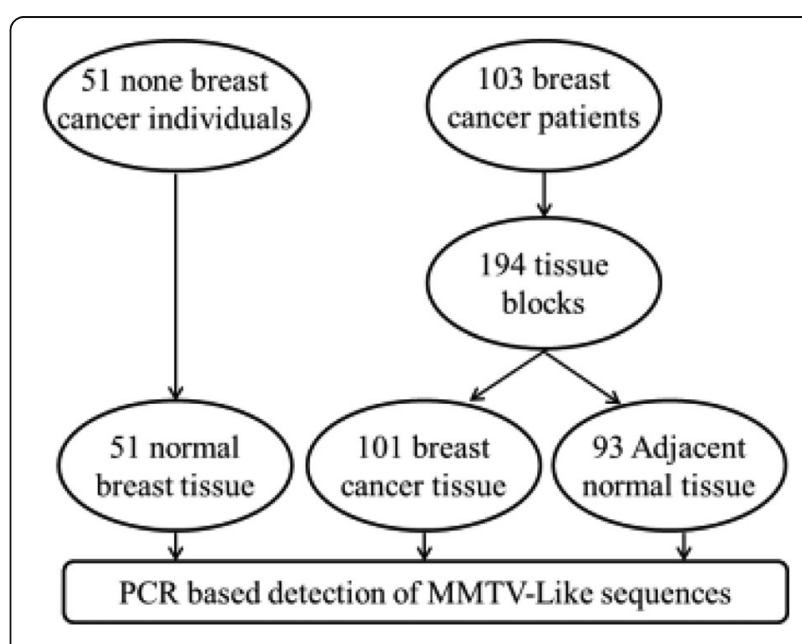

Fig. 1 Schematic representation of the samples and study population 
avoid cross contamination, each sample was processed separately and the microtome blade was brushed and cleaned with alcohol before each use.

\section{DNA and RNA extraction}

Extraction of DNA and RNA was done using Allprep DNA/RNA FFPE kit (Qiagen, Hilden, Germany) according to the manufacturer's instructions. The kit allows simultaneous extraction of DNA and RNA in separate tubes. Quantity and quality of extracted nucleic acid was determined using the NanoDrop 2000 (Thermo Fisher Scientific, Massachusetts, United States). The extracted nucleic acid was stored at $-70 \mathrm{C}$ till the time of analysis.

\section{Polymerase chain reaction}

A fragment from the $\beta$-globin gene was amplified using the following primers beta-globin-F 5-TAAGGTGA AGGCTCATGGCAA-3 and beta-globin-R 5-GCAGCT CACTCAGTGTGGCA-3 and the following conditions $95{ }^{\circ} \mathrm{C}$ for $5 \mathrm{~min}$, and 35 cycles of $95{ }^{\circ} \mathrm{C}$ for $30 \mathrm{~s}, 58^{\circ} \mathrm{C}$ for $30 \mathrm{~s}$, and $72{ }^{\circ} \mathrm{C}$ for $25 \mathrm{~s}$ [20]. For the detection of MMTVenv like sequences, a set of newly designed primers based on the alignment in Fig. 2 (MMTV-F 5'-ATGGGTAGAACCTACWTGGTTCTG-3'and MMTV-R 5'-ATAAG
GRTAAGTAACACAGGCAGA-3') were used according to the following conditions: $94{ }^{\circ} \mathrm{C}$ for $5 \mathrm{~min}$, followed by 35 cycles of $94{ }^{\circ} \mathrm{C}$ for $30 \mathrm{~s}, 53{ }^{\circ} \mathrm{C}$ for $30 \mathrm{~s}$, and $72{ }^{\circ} \mathrm{C}$ for $25 \mathrm{~s}$. Flexi taq polymerase (promega) was used with $2.5 \mathrm{mM} \mathrm{MgCl} 2$ per reaction. Negative, no template control, was included in each run. Positive control (PCR fragment of MMTV env gene kindly provided by Prof. Pogo) was also included in each run. To exclude any possibility of contamination, we have strictly worked in discrete areas of pre and post PCR and the positive control was added separately in another room.

\section{Reverse transcriptase PCR (RT-PCR)}

RNA fraction from the Allprep DNA/RNA FFPE kit was used for RNA extraction. DNase digestion step was performed additionally during the extraction of RNA. The Sensiscript reverse transcription kit (Qiagen, Hilden, Germany) was used to generate cDNA according to the manufacturer's instructions. Two different protocols were used to generate the cDNA; one with Oligo dT primers and the other with random primers (Promega). PCR was then performed to detect the beta-globin and the MMTV-env like transcripts according to the above mentioned protocols.

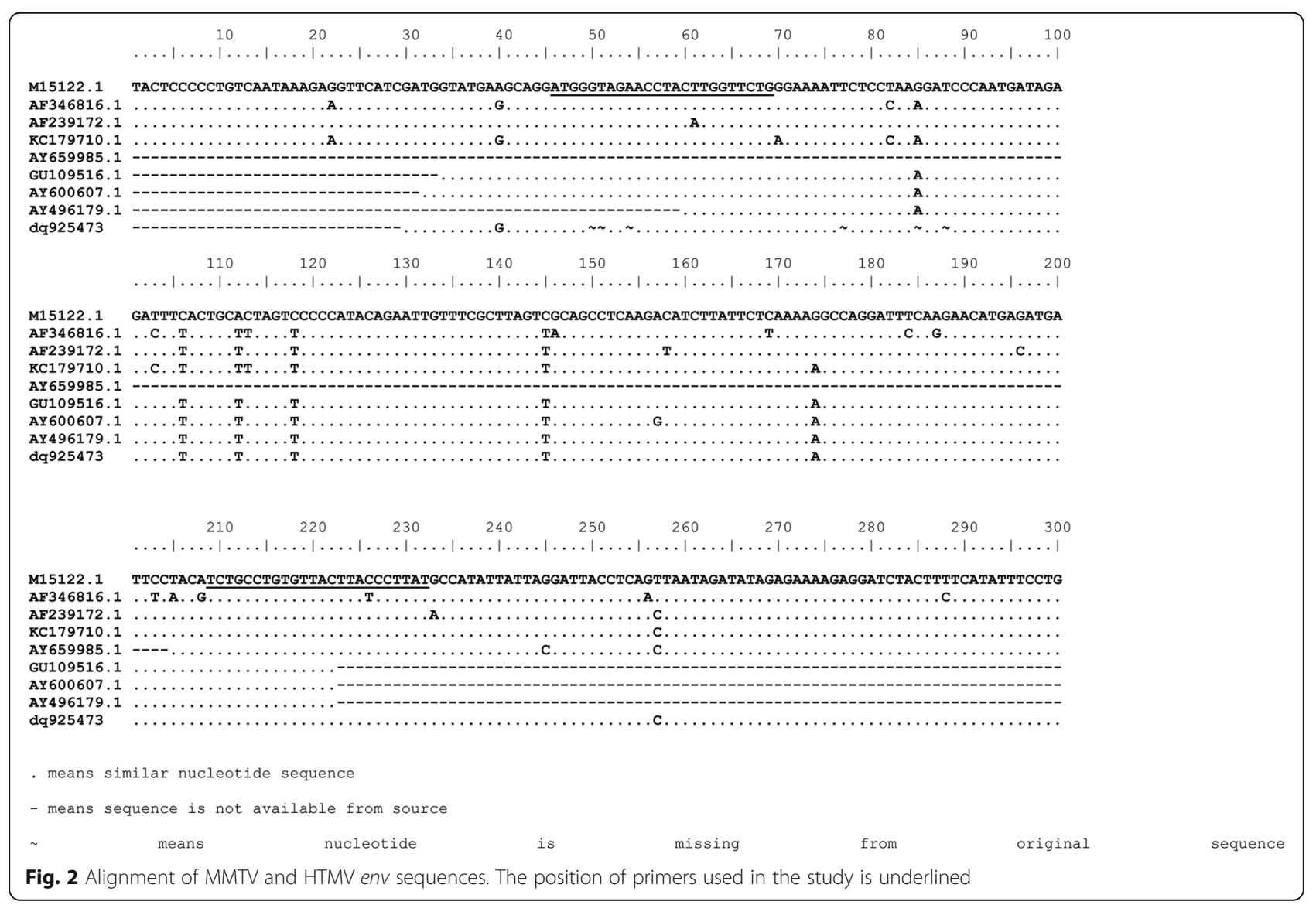




\section{Sequencing}

The MMTV-env like amplified PCR product was excised from the agarose gel. The DNA was purified using Gel extraction kit (Qiagen, Hilden, Germany) and sequenced using the BigDye terminator sequencing and purification kits (Thermo Fisher Scientific, MA, USA) and the genetic analyzer 3500 (Thermo Fisher Scientific, MA, USA).

\section{Results}

The quality of extracted DNA was good as demonstrated by the detection of the $\beta$-globin gene in all samples. To detect the MMTV env like sequences we designed a new set of primers (MMTV-F and MMTV-R) based on an alignment of the human mammary tumor virus (HMTV) sequences from the PubMed database (Fig. 2). The optimum conditions for these primers were first standardized on a serial dilution of the positive control (kindly provided by professor Pogo) (Fig. 3). All samples were then tested using the new primers. Out of 194 samples, fifteen tissue samples (7.7\%) gave positive results (Fig. 4), six (6/ $101,5.9 \%)$ were from cancerous tissues and nine (9/93, 9.7\%) were from non-cancerous surrounding tissues. None of the 51 breast tissues samples from non-breast cancer patients gave positive PCR results.

Out of the 103 breast cancer patients tested, 9 patients (8.7\%) showed evidence of MMTV like env proviral sequences in their breast tissue (Table 1). Six patients (5.8\%) showed MMTV like sequences in both breast cancer tissues and non-cancerous surrounding tissues, none of the patients had MMTV positivity only in cancer tissues and 3 patients (2.9\%) showed positivity only in non-cancerous surrounding tissues but not in cancer tissues (Table 1). The prevalence of MMTV in Saudi breast cancer patients alone was $5.97 \%$. Table 2 shows the prevalence of MMTV in breast cancer from different nationalities in the study.

Despite the use of two different primers, oligo dT and random primers, for the generation of the total cDNA,

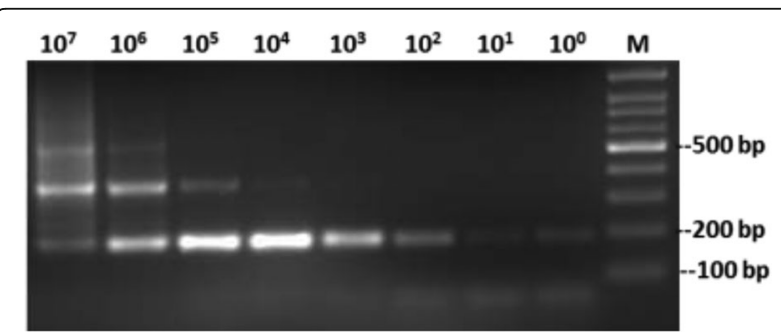

Fig. 3 Sensitivity of the newly designed primers for the detection of MMTV-env like sequences. A serial dilution of the positive control was used as template for the PCR reaction using MMTV F\&R primers. Amplicon size is $187 \mathrm{bp}$. The numbers indicate the calculated copy number of the positive control fragment per microliter. Four microliters were used per reaction. Detection level is 250 copies per ml. (M) 100 bp DNA ladder neither MMTV-env RNA sequence nor $\beta$-globin gene transcripts could be detected in any of the samples.

Sequencing the MMTV-env like PCR product, from eight of the positive samples, showed that it resembles the human mammary tumor virus (HMTV) sequences of the following accession numbers GU109516.1, AY496179.1, and dq925473 with $100 \%$ similarity in the sequenced regions (Fig. 5).

\section{Discussion}

Detection of MMTV env sequences is variable in different parts of the world ranging from $0.8-74 \%$ (Table 3 ). The reason for this geographical variation in addition to the role played by this virus in breast cancer and the mode of transmission are not completely understood. However, there is accumulating evidence supporting the association of this virus with the risk of breast cancer. In fact, Wang et al. performed a systematic search of multiple databases to explore this association and found that the presence of MMTV like virus is associated with increased risk of developing breast cancer and is significantly higher in western countries than in Asian countries [21]. Additionally, MMTV-like sequences of the env gene were found in breast biopsies of Australian females before and after developing breast cancer, a criterion which fulfills a possible causal correlation between the virus and breast cancer [22]. MMTV seems to have jumped into human population in old times through zoonotic transmission from mice and maintained itself using certain routes of transmission. Two routes of transmission, saliva and milk, were documented in literature. MMTV DNA was detected in saliva of breast cancer patients, healthy adults and children but not in newborns [23]. The same study reported the detection of MMTV RNA in saliva of breast cancer patients and their salivary glands suggesting saliva as a route of transmission among humans [23]. MMTV sequences were also detected in the milk of healthy lactating women [24, 25] and lactating women at high risk of developing breast cancer [25] suggesting another route of MMTV transmission among humans.

Interestingly, MMTV pathogenesis in human extends to other diseases. MMTV sequences were detected in liver disease biopsies [26] and was found to be associated with primary biliary cirrhosis [27, 28], autoimmune and idiopathic liver diseases [29]. The association of MMTV with primary biliary cirrhosis was not supported by all studies [30]. However, the mitigation of cholangitis using combination antiretroviral therapy in a mouse model of liver disease support the notion of a role for retrovirus in development of liver disease [28].

Breast cancer in Saudi Arabia, like in other parts of the world, constitutes a major health problem. According to the Saudi Arabian Cancer Incidence Report of 


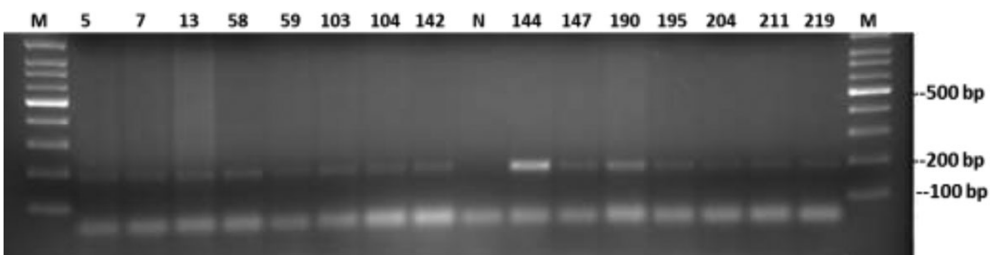

Fig. 4 Samples positive for MMTV-env like sequences. A new DNA extraction was performed from all samples that gave a positive PCR result. The PCR reaction was repeated to confirm the results. (N) Stands for negative control

2010, breast cancer accounts for $15 \%$ of all cancers among Saudis of all ages and $27.4 \%$ of cancers in females. Furthermore, Ibrahim et al. found that breast cancer in Saudi women of the eastern province is characterized by earlier onset and more malignant behavior compared to women in the USA with median age of less than 50 years [19]. Since young age has been identified as an independent risk factor for breast cancer relapse and poor prognosis [31, 32] studies exploring the behavior of breast cancer in Saudi women, its prognostic factors and its pathophysiology are urgently needed.

This study reports, to the best of our knowledge, for the first time the detection of MMTV env sequences in breast cancer tissues from breast cancer patients in Saudi Arabia and in the Arab patients from the Gulf area at all. The prevalence of MMTV like env proviral sequences was
$8.7 \%$ in breast cancer patients in total and $5.97 \%(4 / 67)$ in Saudi patients (Table 2) but the virus was not detectable in breast tissue from non-breast cancer individuals. The small number of non-Saudi patients in the study precluded a firm conclusion about the prevalence of MMTV in females from other nationalities (Table 2). However, clustering patients according to the region of origin suggested that Africa might have higher frequency of MMTV in breast cancer. A separate study with a lager sample size is required to confirm this hypothesis (Table 2). These findings are in concordance with the low prevalence reported in other countries like Mexico [33], Tunisia [34], Japan [35], Australia [17], and Iran [36] (Table 3). However, the prevalence of MMTV positivity in Saudi Arabia is lower than that detected in other studies from Australia [9, 10, 37] Tunisia [38], USA [5-7], Italy [39], Pakistan [40] and Morocco [41] (Table 3).

Table 1 Frequency of MMTV env sequence in relation to age of patient, grade of cancer and lymph node metastasis

\begin{tabular}{|c|c|c|c|c|}
\hline Variables & $\begin{array}{l}\text { frequency of MMTV env positivity in } \\
\text { both tumor and normal tissue } \\
(n=6 / 103) \\
5.8 \%\end{array}$ & $\begin{array}{l}\text { frequency of MMTV env positivity } \\
\text { in tumor }(n=0 / 103) \\
0.0 \%\end{array}$ & $\begin{array}{l}\text { frequency of MMTV env positivity } \\
\text { in normal tissue }(n=3 / 103) \\
2.9 \%\end{array}$ & $\begin{array}{l}\text { Total } \\
(n=9 / 103) \\
8.7 \%\end{array}$ \\
\hline \multicolumn{5}{|l|}{ Age (years) } \\
\hline $20-29$ & 0 & 0 & 0 & 0 \\
\hline $30-39$ & $1(16.7 \%)$ & 0 & $1(33.3 \%)$ & $2(22.2 \%)$ \\
\hline $40-49$ & $1(16.7 \%)$ & 0 & $2(66.7 \%)$ & $3(33.3 \%)$ \\
\hline $50-59$ & $3(50.0 \%)$ & 0 & 0 & $3(33.3 \%)$ \\
\hline $60-69$ & 0 & 0 & 0 & 0 \\
\hline $70-79$ & $1(16.7 \%)$ & 0 & 0 & $1(11.1 \%)$ \\
\hline$P$-value & $0.35^{\mathrm{a}}$ & $\begin{array}{l}\text {-(None reported as the } \\
\text { observed positivity is zero) }\end{array}$ & $0.50^{\mathrm{a}}$ & $0.45^{\mathrm{a}}$ \\
\hline \multicolumn{5}{|l|}{ Grade } \\
\hline 1 & 0 & 0 & $1(33.3 \%)$ & $1(11.1 \%)$ \\
\hline 2 & $2(33.3 \%)$ & 0 & $2(66.7 \%)$ & $4(44.4 \%)$ \\
\hline 3 & $4(66.7 \%)$ & 0 & 0 & $4(44.4 \%)$ \\
\hline$p$-value & $0.69^{a}$ & - & $0.34^{\mathrm{a}}$ & $0.91^{\mathrm{a}}$ \\
\hline \multicolumn{5}{|c|}{ Presence of lymph nodes metastasis } \\
\hline No & $6(100.0 \%)$ & 0 & $2(66.7)$ & 8 (88.9\%) \\
\hline Yes & 0 & 0 & 1(33.3\%) & 1 (11.1\%) \\
\hline$p$-value & $0.003^{\mathrm{a}}$ & - & $0.60^{\mathrm{a}}$ & $0.002^{a}$ \\
\hline
\end{tabular}

${ }^{\mathrm{a}}$ Fisher's exact due to small numbers 
Table 2 MMTV positivity in the study population of different nationalities

\begin{tabular}{|c|c|c|c|c|}
\hline Nationality & Number of patients & MMTV positive patients/number of patients (\%) & Region & $\begin{array}{l}\text { MMTV positive patients/ } \\
\text { number of patients (\%) }\end{array}$ \\
\hline Pakistani & 1 & $0 / 1(0)$ & Asian & $1 / 11(9.1 \%)$ \\
\hline Indian & 4 & $0 / 4(0)$ & & \\
\hline Philippines & 5 & $0 / 5(0)$ & & \\
\hline Sri Lankan & 1 & $1 / 1(100)$ & & \\
\hline Lebanese & 1 & $0 / 1(0)$ & Middle East & $6 / 77(7.8 \%)$ \\
\hline Bahraini & 1 & $1 / 1(100)$ & & \\
\hline Palestinian & 2 & $0 / 2(0)$ & & \\
\hline Jordanian & 2 & $1 / 2(50)$ & & \\
\hline Saudi & 67 & $4 / 67(5.97)$ & & \\
\hline Syrian & 1 & $0 / 1(0)$ & & \\
\hline Yemini & 3 & $0 / 3(0)$ & & \\
\hline Somali & 1 & $0 / 1(0)$ & Africa & $2 / 15(13.3 \%)$ \\
\hline Sudanese & 5 & $1 / 5(20)$ & & \\
\hline Egyptian & 8 & 0/8 (0) & & \\
\hline Moroccan & 1 & $1 / 1(100)$ & & \\
\hline Total & 103 & 9/103 (8.7) & & 9/103 (8.7) \\
\hline
\end{tabular}

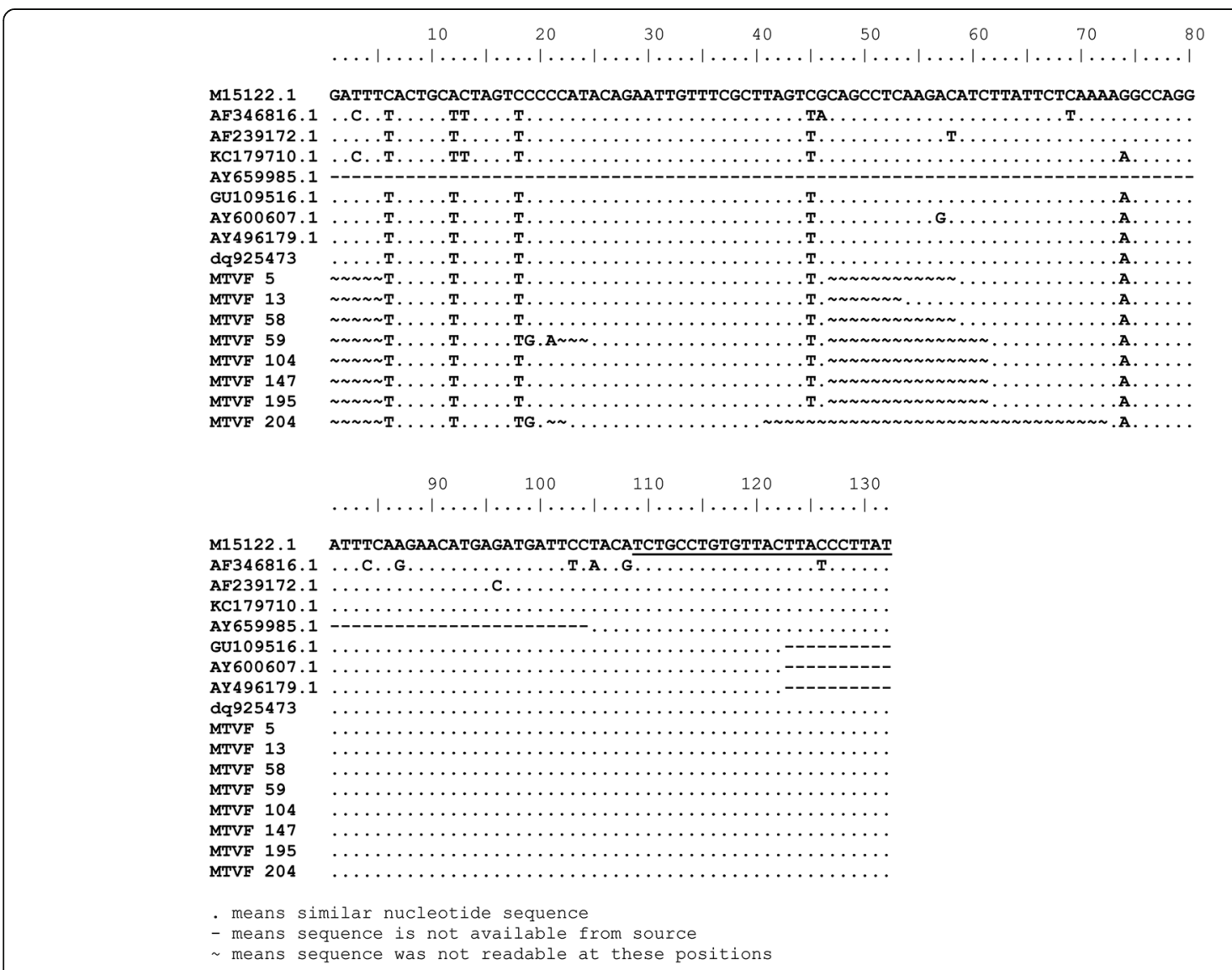

Fig. 5 Alignment of the detected MMTV-like env sequences (MTVF5, 13, 58, 59,104,147,195,204) shows very high similarity to HMTV 
Table 3 Prevalence of MMTV like env sequence in human breast cancer samples and controls in published articles between 1995 and 2014 from different geographical location

\begin{tabular}{|c|c|c|c|c|c|c|}
\hline \multirow[t]{2}{*}{ Year } & \multirow{2}{*}{$\begin{array}{l}\text { Geographic } \\
\text { location }\end{array}$} & \multicolumn{2}{|c|}{ Breast cancer samples } & \multicolumn{2}{|l|}{ Control samples } & \multirow[t]{2}{*}{ Reference } \\
\hline & & Number & $\begin{array}{l}\text { MMTV-like env } \\
\text { positivity no. (\%) }\end{array}$ & Number & $\begin{array}{l}\text { MMTV-like env positivity } \\
\text { no. (\%) }\end{array}$ & \\
\hline 1995 & USA & 314 & $121(38.5 \%)$ & $\begin{array}{l}136 \\
(29 \text { fibroadenoma and } 107 \\
\text { reduction mammoplasty) }\end{array}$ & $4(2.9 \%)$ & {$[5]$} \\
\hline 2000 & USA & 72 & 27 (37\%) & $\begin{array}{l}35 \\
(25 \text { negative biopsy, } 5 \text { reduction } \\
\text { mammoplasty and } 5 \text { adjacent breast tissue) }\end{array}$ & $0(0 \%)$ & {$[7]$} \\
\hline 2001 & USA & 106 & $32(30.1 \%)$ & $\begin{array}{l}106 \\
\text { (paired breast tissue) }\end{array}$ & $1(0.94)$ & {$[6]$} \\
\hline 2003 & Australia & $\begin{array}{l}45 \text { Caucasian } \\
\text { Australian, 120, } \\
\text { Vietnamese } \\
41 \text { Vietnamese- } \\
\text { Australian }\end{array}$ & $\begin{array}{l}19 \text { (42.2\%) Caucasian } \\
\text { Australian, } 1(0.8 \%), \\
\text { Vietnamese } \\
0 \text { (0\%) Vietnamese- } \\
\text { Australian }\end{array}$ & $\begin{array}{l}111 \text { Australian and } 60 \text { Vietnamese } \\
\text { (normal breast tissues) }\end{array}$ & $\begin{array}{l}2(1.8 \%) \text { Australian } \\
\text { and } 0(0 \%) \text { Vietnamese }\end{array}$ & {$[17]$} \\
\hline 2004 & Australia & 128 & $50(40 \%)$ & - & - & {$[43]$} \\
\hline 2004 & Australia & $\begin{array}{l}136 \\
+13 \text { male breast } \\
\text { cancer }\end{array}$ & $\begin{array}{l}43(32 \%) \\
+8(62 \%)\end{array}$ & $\begin{array}{l}164 \\
(111 \text { normal breast tissue,25 fibroadenoma, } \\
4 \text { hyperplasia, } 25 \text { fibrocystic) }+52 \text { male } \\
\text { (gynecomastia) }\end{array}$ & $\begin{array}{l}15(9 \%) \\
+10(19 \%)\end{array}$ & {$[44]$} \\
\hline 2004 & Tunisia & 38 & $28(73 \%)$ & - & - & {$[38]$} \\
\hline 2006 & Italy & 45 & 15 (33\%) & $\begin{array}{l}40 \\
(8 \text { normal breast tissue, } 4 \text { blood from } \\
\text { breast cancer patients, } 20 \text { other } \\
\text { cancers and } 8 \text { blood from healthy blood donor) }\end{array}$ & 0 & [39] \\
\hline 2007 & Mexico & 119 & $5(4.2 \%)$ & - & - & {$[45]$} \\
\hline 2008 & Australia & 50 & $28(56 \%)$ & - & - & [10] \\
\hline 2008 & Tunisia & 122 & 17 (13.9\%) & $\begin{array}{l}122 \\
\text { (adjacent breast tissue) }\end{array}$ & $0(0 \%)$ & {$[34]$} \\
\hline 2008 & Japan & 46 & $0(0 \%)$ & 3 benign breast tumor & $0(0 \%)$ & {$[35]$} \\
\hline 2010 & Australia & 74 & $33(45 \%)$ & $\begin{array}{l}29 \\
\text { (reduction mammoplasty) }\end{array}$ & $0(0 \%)$ & {$[37]$} \\
\hline 2011 & Australia & 42 & $0(0 \%)$ & - & - & {$[46]$} \\
\hline 2012 & Australia & 50 & $39(78 \%)$ & $\begin{array}{l}40 \\
\text { (milk from normal lactating women) }\end{array}$ & $8(32 \%)$ & [9] \\
\hline 2012 & Iran & $\begin{array}{l}50+300 \text { blood } \\
\text { from breast } \\
\text { cancer patient }\end{array}$ & $0(0 \%)$ & $\begin{array}{l}300 \\
\text { (blood from healthy donor) }\end{array}$ & $0(0 \%)$ & {$[36]$} \\
\hline 2013 & Mexico & 86 & $0(0 \%)$ & $\begin{array}{l}65 \\
\text { (adjacent breast tissue) }\end{array}$ & $0(0 \%)$ & {$[47]$} \\
\hline 2013 & Iran & 40 & $0(0 \%)$ & - & - & [48] \\
\hline 2014 & Mexico & 458 & 57 (12.4\%) & $\begin{array}{l}458 \\
\text { (adjacent breast tissue) }\end{array}$ & $72(15.7 \%)$ & [33] \\
\hline 2014 & Pakistan & $\begin{array}{l}80+80 \text { paired } \\
\text { blood samples }\end{array}$ & $16(20 \%)$ & - & - & {$[40]$} \\
\hline 2014 & Morocco & 42 & $24(57 \%)$ & $\begin{array}{l}18 \text { (matched normal breast } \\
\text { tissue from safety margins) }\end{array}$ & $6(33.3 \%)$ & {$[41]$} \\
\hline 2017 & Pakistan & 250 samples & $29.3 \%$ & - & - & [49] \\
\hline 2017 & Myanmar & 58 samples & $1(1.7 \%)$ & - & - & [50] \\
\hline
\end{tabular}

MMTV env-like sequences were detected simultaneously from cancerous and normal tissue from the same patient in most of the positive cases. However, in $2.9 \%$ of the patients, MMTV env-like sequences were detected in normal tissue only. Similar finding was reported from other studies previously $[33,41]$. Detection of the env- 
like sequences from tumor-adjacent normal tissue could indicates that these cells were not yet transformed by the virus and more distant tissue should be used as a control. It could also bring back the discussion about the endogenous origin of the virus. Nonetheless, detection of the virus only in normal tissue supports the notion of the exogenous origin of the virus and that it was not inherited through the germline. Moreover, it proposes a post tumor infection scenario and excludes a role for the virus in formation of the tumor in these patients. We have never worked previously with MMTV or had any of the other laboratories in our institution excluding the possibility of contamination. Additionally, we have strictly worked in discrete areas and the positive control was added separately in another room. Furthermore and to confirm the authenticity of the PCR results, a second DNA extraction and PCR was made for all samples that gave positive results with the first screen (Fig. 4). Furthermore, MMTV proviral sequences were not detected in breast tissue samples collected from patients with no breast cancer.

There was no significant association between MMTV positivity and patients age or grade of tumor, but there was significant association between MMTV positivity in both cancerous and normal adjacent tissue and absence of lymph node metastasis ( $p$ value 0.002) (Table.1). Nevertheless, MMTV positivity was higher in patients with more advanced disease (grade 3 ) in comparison to grade 1 and 2 tumor.

This study adds to the accumulating evidence of the association of MMTV like viruses and human breast cancer particularly advanced tumor and rules out the presence of a significant association between the viral presence and age of the patients and grade of the tumor. At the same time, the low percentage of MMTV positivity $(8.7 \%)$ found in this study could not alone explain the pattern of breast cancer in this area and other studies are needed to further explore the role of the MMTV in breast cancer. Interestingly, a recent study showed that priming mice with the MMTV-p14 signal peptide elicits a protective immune response against MMTV induced tumor and the use of anti-p14 antibodies or the T-cells from p14-immunized mice is an effective therapeutic intervention [42]. This study provides a promising approach for prevention and treatment of MMTVassociated human tumors.

\section{Conclusion}

Using a newly designed PCR based on sequence alignment of available MMTV env sequences, this study detected for the first time in the Arab Gulf region the presence of MMTV env sequences in $9 / 103$ breast cancer patients (8.7\%). In addition, the detection of the sequences in adjacent normal tissues alone in 3 patients (2.9\%) support the hypothesis of the exogenous origin of the virus and therefore provide a baseline for further studies on viral transmission, infectivity and pathogenesis which are highly needed to further understand the role of MMTV in human breast cancer.

\section{Abbreviations}

FFPE: Formalin fixed paraffin embedded; HERV: Human Endogenous Retrovirus; HMTV: Human Mammary Tumor Virus; MMTV env: Mouse Mammary Tumor Virus envelope gene; MMTV: Mouse Mammary Tumor Virus; PCR: polymerase chain reaction; SCRELC: Standard Committee for Research Ethics on Living Creatures

\section{Acknowledgements}

The research team is grateful to the department of pathology at the Imam Abdulrahman Bin Faisal University for providing patients samples. Special thanks to Mr. Nestor Recella for technical assistance throughout the project and to Dr. Reem Al Omar for statistical analysis. We are also grateful for professor Pogo for providing us with the positive control. This project was funded by the Imam Abdulrahman Bin Faisal University deanship of scientific research, project number 2013194.

\section{Funding}

This project was funded by the Imam Abdulrahman Bin Faisal University, deanship of scientific research, project number 2013194. The funding body was not involved in the design of the study, conduction or analysis of the results, their main role is to ensure that the project fulfills the vision, mission and goals of the deanship.

\section{Availability of data and materials}

Technical details and additional data can be obtained by direct communication with the corresponding author.

\section{Authors' contribution}

The corresponding author RA was involved in planning, designing the project, obtaining funds and writing the manuscript. Coauthor KA was mainly involved with project technical design, testing of samples, verification of results and writing and editing the manuscript. Coauthor HA was involved in providing patients samples and patients' data and analysis of results.

All authors reviewed and approved the manuscript.

\section{Ethics approval and consent to participate}

Ethical approval for this study was obtained from the Standard Committee for Research Ethics on Living Creatures (SCRELC) at Imam Abdulrahman Bin Faisal University (IRB approval number IRB-2013-01-006). On the other hand, Informed patient consent was waived by the SCRELC due to the use of archival material of anonymous nature that doesn't disclose patients identity and because patients are lost to follow-up.

\section{Consent for publication}

Not applicable.

\section{Competing interests}

The authors declare that they have no competing interests.

\section{Publisher's Note}

Springer Nature remains neutral with regard to jurisdictional claims in published maps and institutional affiliations.

\section{Author details}

${ }^{1}$ Department of Microbiology, Collage of Medicine, Imam Abdulrahman Bin Faisal University (IAU), 1982, Dammam 31441, Kingdom of Saudi Arabia. ${ }^{2}$ Department of Epidemic Diseases Research, Institute for Research and Medical Consultation, Imam Abdulrahman Bin Faisal University, Dammam 31441, Saudi Arabia. ${ }^{3}$ Department of Pathology, King Fahd Hospital of the University, Imam Abdulrahman Bin Faisal University, Dammam 31441, Saudi Arabia. 
Received: 2 November 2016 Accepted: 29 January 2018

\section{Published online: 09 February 2018}

\section{References}

1. Jemal A, Bray F, Center MM, Ferlay J, Ward E, Forman D. Global cancer statistics. CA Cancer J Clin. 2011;61(2):69-90

2. Coleman MP, Quaresma M, Berrino F, Lutz JM, De Angelis R, Capocaccia R, Baili P, Rachet B, Gatta G, Hakulinen T, et al. Cancer survival in five continents: a worldwide population-based study (CONCORD). Lancet Oncol. 2008;9(8):730-56.

3. Moore DH. Evidence for a human breast cancer virus. Indian J Cancer. 1971; 8(2):80-3.

4. Axel R, Schlom J, Spiegelman S. Presence in human breast cancer of RNA homologous to mouse mammary tumour virus RNA. Nature. 1972; 235(5332):32-6.

5. Wang Y, Holland JF, Bleiweiss IJ, Melana S, Liu X, Pelisson I, Cantarella A, Stellrecht K, Mani S, Pogo BG. Detection of mammary tumor virus env genelike sequences in human breast cancer. Cancer Res. 1995;55(22):5173-9.

6. Melana SM, Holland JF, Pogo BG. Search for mouse mammary tumor viruslike env sequences in cancer and normal breast from the same individuals. Clin Cancer Res. 2001;7(2):283-4.

7. Etkind P, Du J, Khan A, Pillitteri J, Wiernik PH. Mouse mammary tumor viruslike ENV gene sequences in human breast tumors and in a lymphoma of a breast cancer patient. Clin Cancer Res. 2000;6(4):1273-8.

8. Etkind PR, Stewart AF, Wiernik PH. Mouse mammary tumor virus (MMTV)-like DNA sequences in the breast tumors of father, mother, and daughter. Infect Agent Cancer. 2008;3:2.

9. Glenn WK, Heng B, Delprado W, lacopetta B, Whitaker NJ, Lawson JS. Epstein-Barr virus, human papillomavirus and mouse mammary tumour virus as multiple viruses in breast cancer. PLoS One. 2012;7(11):e48788.

10. Mok MT, Lawson JS, lacopetta BJ, Whitaker NJ. Mouse mammary tumor viruslike env sequences in human breast cancer. Int J Cancer. 2008;122(12):2864-70.

11. Wang Y, Go V, Holland JF, Melana SM, Pogo BG. Expression of mouse mammary tumor virus-like env gene sequences in human breast cancer. Clin Cancer Res. 1998:4(10):2565-8.

12. Pogo BG, Holland JF. Possibilities of a viral etiology for human breast cancer. A review Biol Trace Elem Res. 1997;56(1):131-42.

13. Keydar I, Ohno T, Nayak R, Sweet R, Simoni F, Weiss F, Karby S, Mesa-Tejada R, Spiegelman S. Properties of retrovirus-like particles produced by a human breast carcinoma cell line: immunological relationship with mouse mammary tumor virus proteins. Proc Natl Acad Sci U S A. 1984;81(13):4188-92.

14. Melana SM, Nepomnaschy I, Hasa J, Djougarian A, Djougarian A, Holland JF, Pogo BG. Detection of human mammary tumor virus proteins in human breast cancer cells. J Virol Methods. 2010;163(1):157-61.

15. Faff $O$, Murray BA, Erfle $V$, Hehlmann R. Large scale production and purification of human retrovirus-like particles related to the mouse mammary tumor virus. FEMS Microbiol Lett. 1993;109(2-3):289-96.

16. Melana SM, Nepomnaschy I, Sakalian M, Abbott A, Hasa J, Holland JF, Pogo BG. Characterization of viral particles isolated from primary cultures of human breast cancer cells. Cancer Res. 2007:67(18):8960-5.

17. Wang Y, Jiang JD, Xu D, Li Y, Qu C, Holland JF, Pogo BG. A mouse mammary tumor virus-like long terminal repeat superantigen in human breast cancer. Cancer Res. 2004;64(12):4105-11.

18. Pogo BG, Holland JF, Levine PH. Human mammary tumor virus in inflammatory breast cancer. Cancer. 2010;116(11 Suppl):2741-4

19. Ibrahim EM, Al-Mulhim FA, Al-Amri A, Al-Muhanna FA, Ezzat AA, Stuart RK, Ajarim D. Breast cancer in the eastern province of Saudi Arabia. Med Oncol. 1998;15(4):241-7.

20. Zangen R, Harden S, Cohen D, Parrella P, Sidransky D. Mouse mammary tumor-like env gene as a molecular marker for breast cancer? Int J Cancer. 2002;102(3):304-7.

21. Wang F, Hou J, Shen Q, Yue Y, Xie F, Wang X, Jin H. Mouse mammary tumor virus-like virus infection and the risk of human breast cancer: a metaanalysis. Am J Transl Res. 2014;6(3):248-66.

22. Nartey T, Mazzanti CM, Melana S, Glenn WK, Bevilacqua G, Holland JF, Whitaker NJ, Lawson JS, Pogo BG. Mouse mammary tumor-like virus (MMTV) is present in human breast tissue before development of virally associated breast cancer. Infect Agent Cancer. 2017;12:1.

23. Mazzanti CM, Lessi F, Armogida I, Zavaglia K, Franceschi S, Al Hamad M, Roncella M, Ghilli M, Boldrini A, Aretini P, et al. Human saliva as route of inter-human infection for mouse mammary tumor virus. Oncotarget. 2015;6(21):18355-63.
24. Johal H, Ford C, Glenn W, Heads J, Lawson J, Rawlinson W. Mouse mammary tumor like virus sequences in breast milk from healthy lactating women. Breast Cancer Res Treat. 2011;129(1):149-55.

25. Nartey T, Moran H, Marin T, Arcaro KF, Anderton DL, Etkind P, Holland JF, Melana SM, Pogo BG. Human mammary tumor virus (HMTV) sequences in human milk. Infect Agent Cancer. 2014;9:20.

26. Johal H, Scott GM, Jones R, Camaris C, Riordan S, Rawlinson WD. Mouse mammary tumour virus-like virus (MMTV-LV) is present within the liver in a wide range of hepatic disorders and unrelated to nuclear p53 expression or hepatocarcinogenesis. J Hepatol. 2009;50(3):548-54.

27. Xu L, Sakalian M, Shen Z, Loss G, Neuberger J, Mason A. Cloning the human betaretrovirus proviral genome from patients with primary biliary cirrhosis. Hepatology. 2004;39(1):151-6.

28. Sharon D, Mason AL. Role of novel retroviruses in chronic liver disease: assessing the link of human betaretrovirus with primary biliary cirrhosis. Curr Infect Dis Rep. 2015;17(2):460.

29. Wang W, Indik S, Wasilenko ST, Faschinger A, Carpenter EJ, Tian Z, Zhang Y, Wong GK, Mason AL. Frequent proviral integration of the human betaretrovirus in biliary epithelium of patients with autoimmune and idiopathic liver disease. Aliment Pharmacol Ther. 2015;41(4):393-405.

30. Selmi C, Ross SR, Ansari AA, Invernizzi P, Podda M, Coppel RL, Gershwin ME. Lack of immunological or molecular evidence for a role of mouse mammary tumor retrovirus in primary biliary cirrhosis. Gastroenterology. 2004;127(2):493-501.

31. Bollet MA, Sigal-Zafrani B, Mazeau V, Savignoni A, de la Rochefordiere A, Vincent-Salomon A, Salmon R, Campana F, Kirova YM, Dendale R, et al. Age remains the first prognostic factor for loco-regional breast cancer recurrence in young ( $<40$ years) women treated with breast conserving surgery first. Radiother Oncol. 2007;82(3):272-80.

32. Elkum N, Dermime S, Ajarim D, Al-Zahrani A, Alsayed A, Tulbah A, Al Malik O, Alshabanah M, Ezzat A, Al-Tweigeri T. Being 40 or younger is an independent risk factor for relapse in operable breast cancer patients: the Saudi Arabia experience. BMC Cancer. 2007;7:222.

33. Cedro-Tanda A, Cordova-Solis A, Juarez-Cedillo T, Pina-Jimenez E, HernandezCaballero ME, Moctezuma-Meza C, Castelazo-Rico G, Gomez-Delgado A, MonsalvoReyes AC, Salamanca-Gomez FA, et al. Prevalence of HMTV in breast carcinomas and unaffected tissue from Mexican women. BMC Cancer. 2014;14:942.

34. Hachana M, Trimeche M, Ziadi S, Amara K, Gaddas N, Mokni M, Korbi S. Prevalence and characteristics of the MMTV-like associated breast carcinomas in Tunisia. Cancer Lett. 2008;271(2):222-30.

35. Fukuoka $H$, Moriuchi $M$, Yano $H$, Nagayasu $T$, Moriuchi $H$. No association of mouse mammary tumor virus-related retrovirus with Japanese cases of breast cancer. J Med Virol. 2008;80(8):1447-51.

36. Motamedifar M, Saki M, Ghaderi A. Lack of association of mouse mammary tumor virus-like sequences in Iranian breast cancer patients. Med Princ Pract. 2012;21(3):244-8.

37. Lawson JS, Glenn WK, Salmons B, Ye Y, Heng B, Moody P, Johal H, Rawlinson WD, Delprado W, Lutze-Mann L, et al. Mouse mammary tumor virus-like sequences in human breast cancer. Cancer Res. 2010;70(9):3576-85.

38. Levine PH, Pogo BG, Klouj A, Coronel S, Woodson K, Melana SM, Mourali N, Holland JF. Increasing evidence for a human breast carcinoma virus with geographic differences. Cancer. 2004;101(4):721-6.

39. Zammarchi F, Pistello M, Piersigilli A, Murr R, Di Cristofano C, Naccarato AG, Bevilacqua G. MMTV-like sequences in human breast cancer: a fluorescent PCR/laser microdissection approach. J Pathol. 2006;209(4):436-44.

40. Naushad W, Bin Rahat T, Gomez MK, Ashiq MT, Younas M, Sadia H. Detection and identification of mouse mammary tumor virus-like DNA sequences in blood and breast tissues of breast cancer patients. Tumour Biol. 2014;35(8):8077-86.

41. Slaoui M, El Mzibri M, Razine R, Qmichou Z, Attaleb M, Amrani M. Detection of MMTV-like sequences in Moroccan breast cancer cases. Infect Agent Cancer. 2014;9:37.

42. Braitbard O, Roniger M, Bar-Sinai A, Rajchman D, Gross T, Abramovitch H, La Ferla M, Franceschi S, Lessi F, Naccarato AG, et al. A new immunization and treatment strategy for mouse mammary tumor virus (MMTV) associated cancers. Oncotarget. 2016;7(16):21168-80.

43. Faedo M, Ford CE, Mehta R, Blazek K, Rawlinson WD. Mouse mammary tumor-like virus is associated with p53 nuclear accumulation and progesterone receptor positivity but not estrogen positivity in human female breast cancer. Clin Cancer Res. 2004;10(13):4417-9. 
44. Ford CE, Faedo M, Crouch R, Lawson JS, Rawlinson WD. Progression from normal breast pathology to breast cancer is associated with increasing prevalence of mouse mammary tumor virus-like sequences in men and women. Cancer Res. 2004;64(14):4755-9.

45. Zapata-Benavides P, Saavedra-Alonso S, Zamora-Avila D, Vargas-Rodarte C, Barrera-Rodriguez R, Salinas-Silva J, Rodriguez-Padilla C, Tamez-Guerra R,

Trejo-Avila L. Mouse mammary tumor virus-like gene sequences in breast cancer samples of Mexican women. Intervirology. 2007;50(6):402-7.

46. Park DJ, Southey MC, Giles GG, Hopper JL. No evidence of MMTV-like env sequences in specimens from the Australian breast cancer family study. Breast Cancer Res Treat. 2011;125(1):229-35.

47. Morales-Sanchez A, Molina-Munoz T, Martinez-Lopez JL, Hernandez-Sancen P, Mantilla A, Leal YA, Torres J, Fuentes-Panana EM. No association between Epstein-Barr virus and mouse mammary tumor virus with breast cancer in Mexican women. Sci Rep. 2013;3:2970.

48. Tabriz HM, Zendehdel K, Shahsiah R, Fereidooni F, Mehdipour B, Hosseini ZM. Lack of detection of the mouse mammary tumor-like virus (MMTV) Env gene in Iranian women breast cancer using real time PCR. Asian Pac J Cancer Prev. 2013;14(5):2945-8.

49. Naushad W, Surriya O, Sadia H. Prevalence of EBV, HPV and MMTV in Pakistani breast cancer patients: a possible etiological role of viruses in breast cancer. Infect Genet Evol. 2017:54:230-7.

50. San TH, Fujisawa M, Fushimi S, Yoshimura T, Ohara T, Soe L, Min NW, Kyaw O, Yang X, Matsukawa A. Low prevalence of human mammary tumor virus (HMTV) in breast cancer patients from Myanmar. Infect Agent Cancer. 2017;12:20.

\section{Submit your next manuscript to BioMed Central and we will help you at every step:}

- We accept pre-submission inquiries

- Our selector tool helps you to find the most relevant journal

- We provide round the clock customer support

- Convenient online submission

- Thorough peer review

- Inclusion in PubMed and all major indexing services

- Maximum visibility for your research

Submit your manuscript at www.biomedcentral.com/submit 